\title{
Anatomical Description of the Fruit-Receptacle Detachment Area in Cayenne Pepper
}

\author{
Kay P. Gersch,' Carl E. Motsenbocker, ${ }^{2}$ and Gregory A. Lang ${ }^{3}$ \\ Department of Horticulture, Louisiana Agricultural Experiment Station, Louisiana State University \\ Agricultural Center, Baton Rouge, LA 70803
}

Addrional indeX words. Capsicum annuum, fruit detachment force, sclereids, histochemical, stereological, abscission

\begin{abstract}
Of eight genotypes of cayenne pepper (Capsicum annuum L.) examined, two were identified that differ significantly in ease of fruit detachment force. Greenhouse and field-grown plants of these genotypes, Cajun 1-9027 and Cap-9004, were investigated for differences in cell type and organization at the fruit and receptacle junction. Scanning electron microscopy revealed that mature Cajun 1-9027 fruit that did not separate exhibited a distinct region of sclerified cells that extended from the periphery of the fruit into the receptacle for $\mathbf{2 5}$ to $\mathbf{3 0}$ cell layers. In contrast, mature fruit of the more readily detachable Cap-9004 had 10 to 15 layers of sclerified cells at the region of detachment. Histochemical and stereological techniques indicated that Cajun 1-9027 had a greater volume of sclereids than Cap-9004. Cajun 1-9027 exhibited smaller cortical cells in the detachment region than Cap-9004. Neither genotype exhibited a well-defined abscission zone at maturity in the detachment region. The presence of more sclerified cells and increased lignification in Cajun 1-9027 compared to Cap-9004 probably contributed to the differences in ease of detachment between the two genotypes.
\end{abstract}

Worldwide production of cultivated pepper (Capsicum spp.) is increasing in economic importance. There are $\approx 50,000$ ha of commercially grown pepper in the United States, of which $16 \%$ are pungent types (Petoseed, 1993). In Mexico, there are 83,000 ha in pepper production; of this $<5 \%$ are sweet (primarily for export). There is a trend of increasing consumption of hot and mildly pungent specialty peppers and/or pepper products. United States production of pungent peppers has increased markedly with increased use of spices (Smith et al., 1987). In the United States, the retail processing industry for cayenne hot sauce is $\$ 60$ to $\$ 70$ million and expanding (Petoseed, 1993).

Pepper harvesting is often difficult and a major expense in production. In most of the cultivated pepper types of C. annuum, including cayenne, the fruit adheres tightly to the receptacle leaving the calyx and pedicel attached when harvested. Tight adherence of the fruit to the receptacle is an important characteristic for hot sauce, as the woody pedicel and green calyx impart offcolor and decrease sauce quality. Consequently, processors limit the amount of pepper with pedicel attached to $5 \%$ due to quality considerations. Currently, most cayenne pepper for hot sauce industry is hand harvested. Mechanical harvest is not practical because of the difficulty in fruit removal, as extensive damage to the fruit and plant may occur. In addition, hand labor would be required to remove the calyx from fruit harvested mechanically.

Received for publication 5 Aug. 1996. Accepted for publication 18 Aug. 1997. Approved for publication by the director of the Louisiana Agricultural Experiment Station as manuscript no. 96-28-0097. We gratefully appreciate the assistance of Raoul Machiavelli with statistical analyses and the technical assistance of Cheryl Crowder and the staff of the Louisiana State Univ. Veterinary School Histology Laboratory, Baton Rouge. Appreciation is also expressed to Sharon Mathews for providing technical assistance in the Life Science Microscopy Facility, Baton Rouge. We thank Marshall Sundberg and William Young for their critical manuscript review and helpful comments. Mention of a trademark, proprietary product, or vendor does not imply endorsement of the product named nor criticism of similar ones not named. The cost of publishing this paper was defrayed in part by the payment of page charges. Under postal regulations, this paper therefore must be hereby marked advertisement solely to indicate this fact.

'Graduate student.

${ }^{2}$ Associate professor.

${ }^{3}$ Associate professor. Current address: IAREC, Washington State Univ., Prosser, WA 99350 .
Because of the problems associated with mechanical and hand fruit removal of cayenne pepper, a better understanding of pepper fruit detachment is needed.

Pepper fruit detachment force (FDF) has been reported to be controlled genetically (Smith, 1951; Spasojevec and Webb, 1971). FDF also has been descriptively correlated to other fruit characteristics. Fruit length, width, and mass correlated with FDF in progeny of crosses of a banana and a cayenne-type pepper (Werner and Honma, 1980). Other correlations of length and diameter of pedicel and fruit to FDF were observed in most segregating generations of crosses between 'Serrano Chili' (low FDF) and three other cultivars, 'Anaheim Chili', 'Keystone Resistant Giant', and 'Red Cherry Small' (high FDF) (Setiamihardja and Knavel, 1990). Abscission of reproductive structures in pepper is most frequently caused by environmental factors and appears to be mediated by hormones, particularly ethylene and auxin (Wien et al., 1989). Plant growth regulators used to increase uniformity of ripening have promoted pepper fruit abscission (Batal and Granberry, 1982; Beaudry and Kays, 1988). Pepper FDF has been measured for separation at the pedicel-stem (Setiamihardja and Knavel, 1990) and the fruit-receptacle junctions (Werner and Honma, 1980). In addition to the above studies on C. annuum, there has also been some recent work on FDF in C. frutescens $\mathrm{L}$. (Motsenbocker, 1996). Little is known, however, of the anatomy or histochemistry of the $C$. annuum fruit-receptacle detachment area. The objectives of this study were to quantify the differences in fruit detachment force and any related fruit characteristics in selected cayenne genotypes and to evaluate genotypic differences in cell type and organization in the fruit-receptacle detachment area and relate these differences to FDF.

\section{Materials and Methods}

\section{Screening genotypes for differential FDF}

GreEnHOUSE STUdiES. On 18 Dec. 1992, eight cayenne pepper genotypes (C 19-9008, C 19-9012, Cap-9004, C 16-9006, Cap9016, Durk-9026, Cajun 1-9027, and Cajun 1-9041) were sown in 72-cell trays with commercial medium (Metro Mix 200; Grace Sierra, Milpitas, Calif.). These genotypes were roughly similar on characteristics of size of calyx, shoulder area, and difference in 
ease of detachment by hand-testing during previous field observations. Seedlings were transplanted on 29 Jan. 1993 into 12-L pots filled with a modified commercial medium (Metro Mix 700; Marysville, Ohio) supplemented with micronutrients (Micromax; Grace Sierra, Milpitas, Calif.) at $0.6 \mathrm{~g} \cdot \mathrm{L}^{-1}$, dolomitic limestone (Easy Line; Sylacauga, Ala.) at $4.8 \mathrm{~g} \cdot \mathrm{L}^{-1}$ and slow-release fertilizer (Osmocote 14N-6.2P-11.6K; Scott Sierra, Marysville, Ohio) at 3.6 $\mathrm{g} \cdot \mathrm{L}^{-1}$. The plants were grown under natural daylight with two diurnal irrigations and standard cultural practices for pest control (Boudreaux et al., 1992). The plants were placed on benches $1 \mathrm{~m}$ apart in staggered double rows arranged in a randomized complete-block design with five blocks. Two fruit were randomly harvested from each plant weekly for 5 weeks, beginning 18 May 1993. Fruits were sampled at the mature red stage with some pericarp wrinkle. Statistical analyses were performed on the means from each plant for each harvest.

FDF was measured using a push-pull force gauge graduated in 25 -g increments up to $2.5 \mathrm{~kg}$ (John Chatillon and Sons, Greensboro, N.C.) modified according to Werner and Honma (1980) and attached to a stand. The pedicel was firmly clamped proximal to the calyx between the steel bar and adjustable bar on the clamp. FDF was determined by slowly pulling the fruit perpendicular to the longitudinal axis of the pedicel-fruit system until the fruit detached from the pedicel. Force gauge readings were recorded in kilograms and converted to Newtons. Other characters measured included fruit length and diameter, pedicel length, calyx diameter, length, and scar. Fruit length was measured as the distance from pedicel attachment at the calyx to its apex. Fruit diameter was measured at its maximum width. Pedicel length was measured as the distance between the points of attachment to the stem and to the calyx. Calyx diameter was measured at the distal end of the calyx. Calyx length was measured from the point of attachment to the pedicel to the distal end. The scar diameter was measured on the fruit after the calyx was removed. All measurements were made with vernier calipers except fruit length, which was measured with a metal metric ruler. Correlations were performed for each genotype between these characteristics and FDF.

Field studies. Based on the results of the preliminary greenhouse study, four genotypes were selected for the field study. Two hard-detaching (Cajun 1-9027, Cajun 1-9041) and two easydetaching genotypes (Cap-9004 and Durk-9026) were seeded on 22 Mar. 1993 and transplanted on 10 May 1993 into plots. The black-plastic-mulched plots had been spray-painted with aluminum. Plots consisted of three plants of each genotype arranged in a split-plot design, with genotypes as the main plot (in four complete blocks) and four harvest dates as subplot treatments. Standard cultural practices (Boudreaux et al, 1992) were followed. To sequence fruit maturity, all mature red fruit were removed and after $3 \mathrm{~d}$ the remaining fruit that had turned red were tagged. The tagged fruit were harvested $4 \mathrm{~d}$ after tagging. Each fruit was carefully removed from the stem leaving the pedicel intact. The first harvest was 10 Aug. 1993. Four of the harvested fruit were randomly selected from each plot to determine FDF. The means from each plot were used in the statistical analysis.

\section{Anatomical and histochemical studies}

Plant material. Fruit of two cayenne pepper genotypes, Cajun 1-9027 and Cap-9004, were collected from field-grown plants in 1993 and greenhouse-grown plants in 1994. Cajun 19027 fruit does not separate and Cap-9004 separates with applied force at the fruit-receptacle junction. Fruit were tagged and harvested as in the field experiment above. Samples were randomly selected from these harvests for anatomical and histochemical studies. To quantify the location of the detachment area at the fruitreceptacle junction, 223 peppers of Cap-9004 were hand separated and the area of separation was observed.

ANatomical studies. Longitudinal tissue samples, $\approx 0.6 \times 0.3$ $\mathrm{cm}$, were prepared to include the region of future detachment, located at the fruit-receptacle junction. About equal portions of fruit and pedicel were included. Samples were placed immediately into $5: 5: 90,37 \%$ formaldehyde : glacial acetic : $70 \%$ ethanol (FAA), by volume, and subjected to a mild vacuum for 24 to $48 \mathrm{~h}$.

LiGHT MICROSCOPY (LM). FAA-fixed samples were dehydrated and embedded in paraffin using standard techniques (Jensen, 1962). Sections were cut at 5 to $10 \mu \mathrm{m}$ using disposable blades on a rotary microtome. To analyze general cellular structure, sections were stained with $0.5 \%$ toluidine blue or $1.0 \%$ safranin counterstained with $1.0 \%$ alcian blue. For histochemical studies, slides were stained with ruthenium red for pectin localization, periodic acid-Schiff's (PAS) reagent for insoluble polysaccharide detection, iodine-potassium iodide (IKI) to observe starch distribution, and phloroglucinol and $\mathrm{HCl}$ for lignin detection (Jensen, 1962). Polarized light was used in addition to the last two tests (Berlyn and Miksche, 1976).

SCANNing EleCtron Microscopy (SEM). FAA-fixed samples were dehydrated with ethanol. The samples were critical-point dried with $\mathrm{CO}_{2}$, mounted on $\mathrm{Al}$ stubs with double-sided tape, and sputter coated with $20 \mathrm{~nm}$ of gold palladium. Observations and photographs were made on a stereoscan scanning electron microscope (model 260; Leica Cambridge) operated at $8 \mathrm{kV}$.

Quantitative analysis. Stereological techniques were applied to quantitate volume densities of the various cell types in the two genotypes (Toth, 1982). Four fruit of each genotype were randomly sampled and tissue sections were prepared as described in LM. Photomicrographs were made with a final magnification $50 \times$. A transparency, marked with boundaries equivalent to $2 \mathrm{~mm}$ on either side of the fruit-receptacle indentation distal to the pedicel, was secured to the photomicrograph. A second transparency with a grid was randomly placed on the photomicrographs and point counts were recorded. Volume densities of parenchyma, sclerenchyma, vascular tissue, and intercellular spaces were calculated from the point counts. Volume densities of the various cell types in the two genotypes were compared with the $\mathrm{z}$ statistic, $P$ $<0.05$.

Table 1. Correlation coefficients for association of fruit detachment force with fruit length or diameter, calyx length, diameter, or scar, and pedicel length.

\begin{tabular}{lccrrrrr}
\hline & \multicolumn{2}{c}{ Fruit } & & & \multicolumn{2}{c}{ Calyx } & Pedicel \\
\cline { 2 - 3 } Genotype & Length & Diam & & Length & Diam & Scar \\
\hline Cap-9004 & $0.39^{* *}$ & 0.09 & & -0.12 & -0.12 & -0.09 & -0.05 \\
C 16-9006 & 0.11 & -0.28 & & -0.03 & -0.17 & 0.29 & -0.03 \\
C 19-9012 & 0.27 & $0.34^{*}$ & & -0.18 & 0.28 & 0.02 & $0.38^{* *}$ \\
Cap-9016 & 0.00 & 0.17 & & 0.07 & -0.20 & 0.00 \\
Durk-9026 & -0.07 & 0.05 & 0.15 & -0.19 & -0.06 \\
\hline
\end{tabular}

\footnotetext{
Significant at $P=0.05$ and 0.01 , respectively.
} 


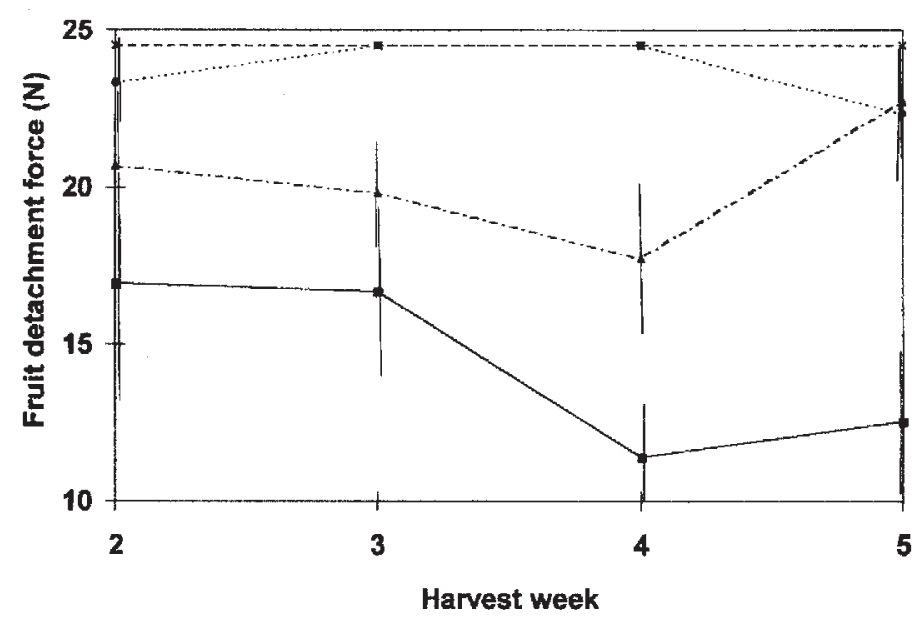

Fig. 1. Fruit detachment force (FDF) of four caycnne pepper genotypes for four harvests in the greenhouse. Cap-9004 ( $\mathbf{\square}$ ), Durk-9026 (A), Cajun 1-9027 (O), Cajun 1-9041 (*). Vertical bars represent SF of the means; error bars that do not appear on graphs are smaller than symbols.

\section{Results}

\section{Screening genotypes for differential FDF}

GreENHOUSE STUDIEs. FDF varied considerably between the eight genotypes. The variation in FDF ranged from high $(>24.5 \mathrm{~N}$, fruit would tear before detachment occurred) to low $(<19.6 \mathrm{~N})$ values. Some genotypes had intermediate FDF and other genotypes had extreme variation over the four harvests. Three of the genotypes, C 19-9008, Cajun 1-9027, and Cajun 1-9041, did not vary in FDF (data not shown). Differences in rate of maturation reduced the number of red fruit available from the first harvest, therefore only the second through fifth harvests were included in the analysis. Linear correlations of FDF with fruit characters were examined for the five genotypes that varied in FDF (Table 1). No significant correlations between FDF and fruit characteristics were consistent over the five genotypes examined. There was, however, a significant correlation of FDF to fruit length for Cap9004. FDF was also significantly correlated to pedicel length and fruit diameter for C 19-9012. No significant correlations were observed between FDF and calyx length, diameter, or scar diameter for the five genotypes studied.

Four of the eight genotypes were selected for further study: two (Cajun 1-9027 and Cajun 1-9041) with high FDF values and two (Cap-9004 and Durk-9026) with low FDF values (Fig. 1). Contrasts indicated significant differences between the two genotypes with high FDF when compared with the two with low FDF for all four harvests. Contrasts also indicated that Cap-9004 FDF was significantly lower than that of Cajun 1-9027 for all four harvests.

Field stunies. FDF values varied over the harvest period; differences in fruit detachment between genotypes were apparent for harvests two, three, and four (Fig. 2). Contrasts of the two high (Cajun 1-9027 and Cajun 1-9042) with the two low FDF genotypes (Cap-9004 and Durk-9026) indicated significant differences for all four harvests. In addition, contrasts indicated that FDF values for Cap-9004 and Cajun 1-9027, two genotypes that had similar fruit characters, were significantly different for harvests two through four.

\section{Anatomical and histochemical studies}

Anatomy of Detachment AREA. The fruit-receptacle detachment area was delineated externally by the fruit-receptacle inden- tation (Fig. 3). The area of study included a region $2 \mathrm{~mm}$ into the fruit and receptacle from the indentation. The vascular cylinder supplying the fruit branched in this region and entered the fleshy pericarp.

Of the 223 fruit of Cap-9004 separated to characterize where detachment takes place, $25 \%$ separated clean (little, or no fruit left attached) at the fruit-receptacle junction just distal to the fruitreceptacle indentation (Fig. 4). More than half (55\%) separated proximal (in this case, xylem strands were broken and protruding) to the fruit-receptacle junction. These separations were in varied positions, from just proximal, to leaving a portion of the pedicel attached (data not shown). The remaining $20 \%$ separated either distally, with fruit tissue attached, or fruit detached unevenly. Other than the clean detachment, no other detachment appeared consistent.

SEM revealed that mature Cajun 1-9027 fruit, which do not separate, exhibited a distinct region of sclerified cells that extended from the periphery of the fruit into the receptacle for 25 to 30 cell layers (Fig. 3b). In comparison, mature fruit of the more readily detachable genotype Cap-9004 had 10 to 15 layers of sclerified cells at the point of detachment (data not shown).

LM revealed that the transition region between the fruit and receptacle outside the vascular cylinder was characterized by progressively smaller cells from the receptacle and fruit toward the juncture of the two tissues in both genotypes. In Cajun 1-9027, the cells in the transition region were sclerified and continued from the cortex ( $\approx 30$ to $38 \mu \mathrm{m}$ ) through the pith $(25$ to $49 \mu \mathrm{m})$ to form a disk of small sclerified cells that extended from the receptacle into the fruit (Fig. 5a). Cells proximal to the transition region in the cortex (73 to $107 \mu \mathrm{m})$ and pith $(67$ to $105 \mu \mathrm{m})$ were similar in size to cells distal to this region in the cortex (60 to $96 \mu \mathrm{m}$ ) and pith ( 58 to 98 $\mu \mathrm{m})$. Cells in the surrounding areas were larger than cells in the transition region. Cap-9004 also exhibited small sclerified cells in the transition region that were mainly confined to the cortex ( 20 to $32 \mu \mathrm{m}$ ) of the fruit-receptacle area (Fig. 5b). The sclerified cells in the pith in Cap-9004, however, were not continuous with the sclereids in the cortex, and the cells in the pith (59 to $117 \mu \mathrm{m})$ were larger than sclereids in the cortex, with no apparent reduction in size from adjacent cells in the receptacle ( 76 to $122 \mu \mathrm{m}$ ) and fruit (68 to $116 \mu \mathrm{m})$ (Fig. 5b).

Histochemistry of DETACHMENT AREA. Localization data for

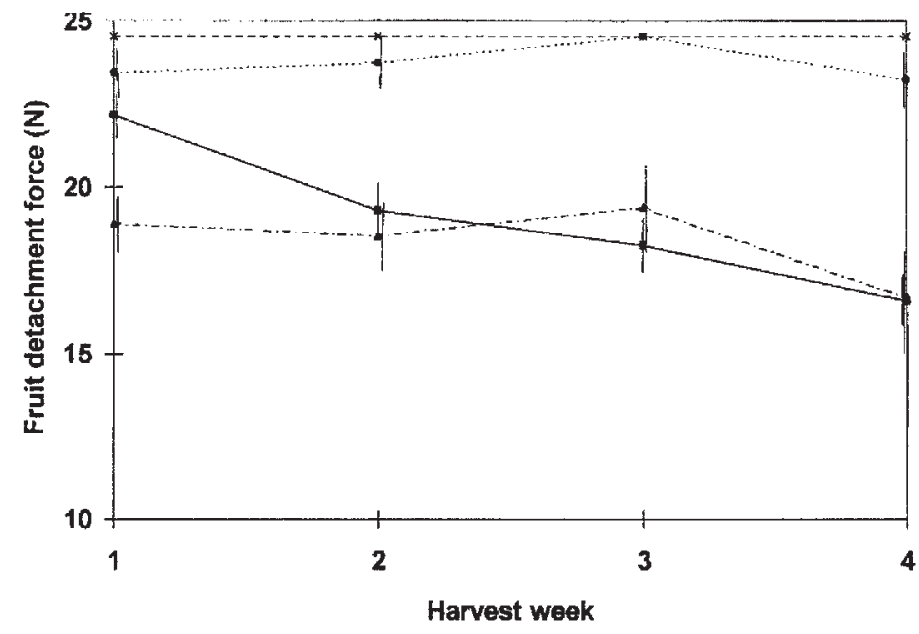

Fig. 2. Fruit detachment force (FDF) of four cayenne pepper genotypes for four harvests in the field. Cap-9004 ( $\mathbf{0}$ ), Durk-9026 ( $\mathbf{\Delta}$ ), Cajun 1-9027 (O), Cajun 1$\left.9041{ }^{*}\right)$. Vertical bars represent SE of the means; error bars that do not appear on graphs are smaller than symbols. 

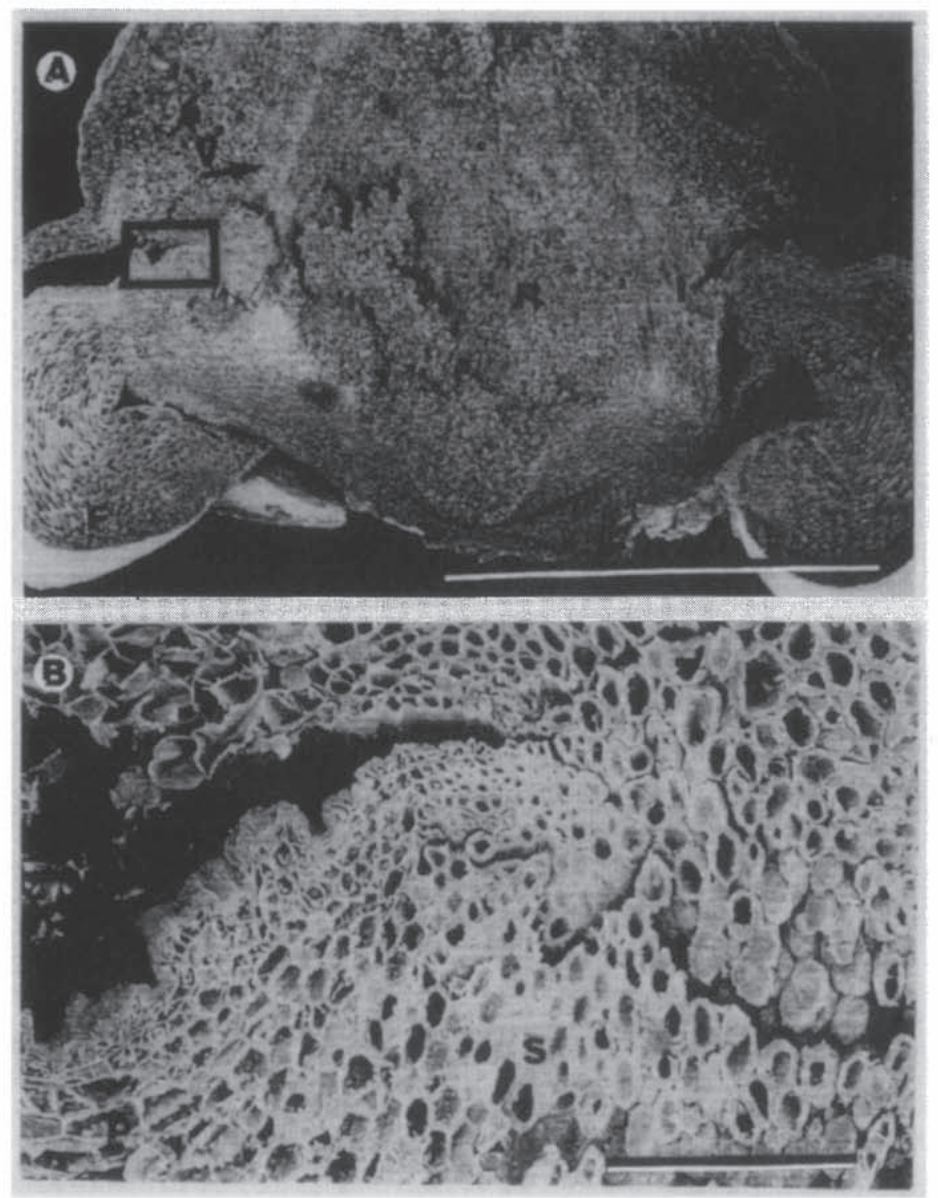

Fig. 3. Scanning electron microscope images illustrating the fruit-receptacle junction in Cajun 1-9027. (A) Longitudinal tissue section, line represents $5 \mathrm{~mm}$. (B) Enlargement of fruit-receptacle indentation outlined in $\mathbf{A}$. Receptacle $=\mathbf{R}$, fruit $=\mathrm{F}$, vascular tissue $=\mathrm{V}$, indentation $=\mathrm{I}$, sclerenchyma $=\mathrm{S}$, parenchyma $=$ P. Line represents $200 \mu \mathrm{m}$.

insoluble polysaccharides and pectins revealed no change through the detachment area of either genotype compared to the adjacent fruit and receptacle tissue (data not shown). Cajun 1-9027 stained intensely in the detachment area and surrounding fruit tissue in both tests, indicating a dense cell structure. In comparison, Cap-

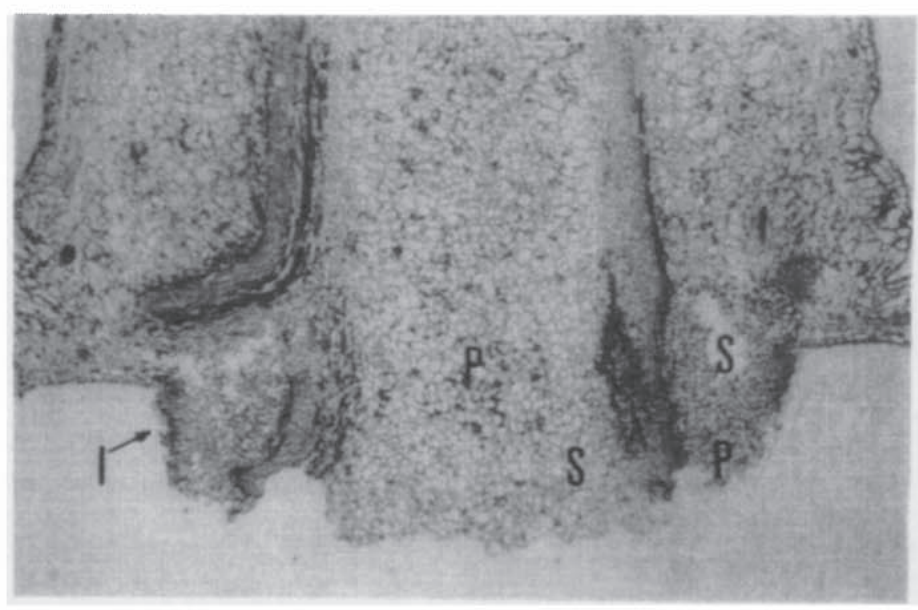

Fig. 4. Photomicrographs of longitudinal sections of separated cayenne pepper fruit stained with $1.0 \%$ safranin counterstained with $1.0 \%$ alcian blue. Cap-9004. Indentation $=\mathrm{I}$, parenchyma $=\mathrm{P}$, and sclerenchyma $=\mathrm{S}$. Magnification $15 \times$.
9004 stained less intensely in this region, suggesting a less-dense structure.

Localization of starch indicated little or no starch in the detachment area (data not shown). Starch was, however, present in the receptacle and the fruit tissue of both genotypes.

Lignified cells were present throughout the fruit-receptacle area in Cajun 1-9027 (data not shown). Based on stain density, there was less lignification in the detachment area in Cap-9004 (data not shown). Sclereids and xylem cells gave a positive reaction for lignin with phloroglucinol and $\mathrm{HCl}$. Polarized light indicated thickened secondary cell walls and confirmed the lignin test (Fig. 6).

QUANTITATIVE COMPosition. The volume density calculated for parenchyma was significantly greater $(P=0.001)$ in Cap-9004 (0.581) than Cajun 1-9027 (0.484) (Table 2). In comparison, the volume density calculated for sclerenchyma was significantly greater $(P=0.001)$ in Cajun 1-9027 (0.409) than in Cap-9004 (0.294). There was no significant difference in volume density of vascular tissue between the two genotypes. The volume density of intercellular spaces was significantly greater $(P=0.001)$ in Cap9004 (0.032) than in Cajun 1-9027 (0.008).

\section{Discussion}

Differences were found in FDF for the genotypes examined in greenhouse and field studies. Similar results for genotypes in greenhouse and field studies are consistent with other research
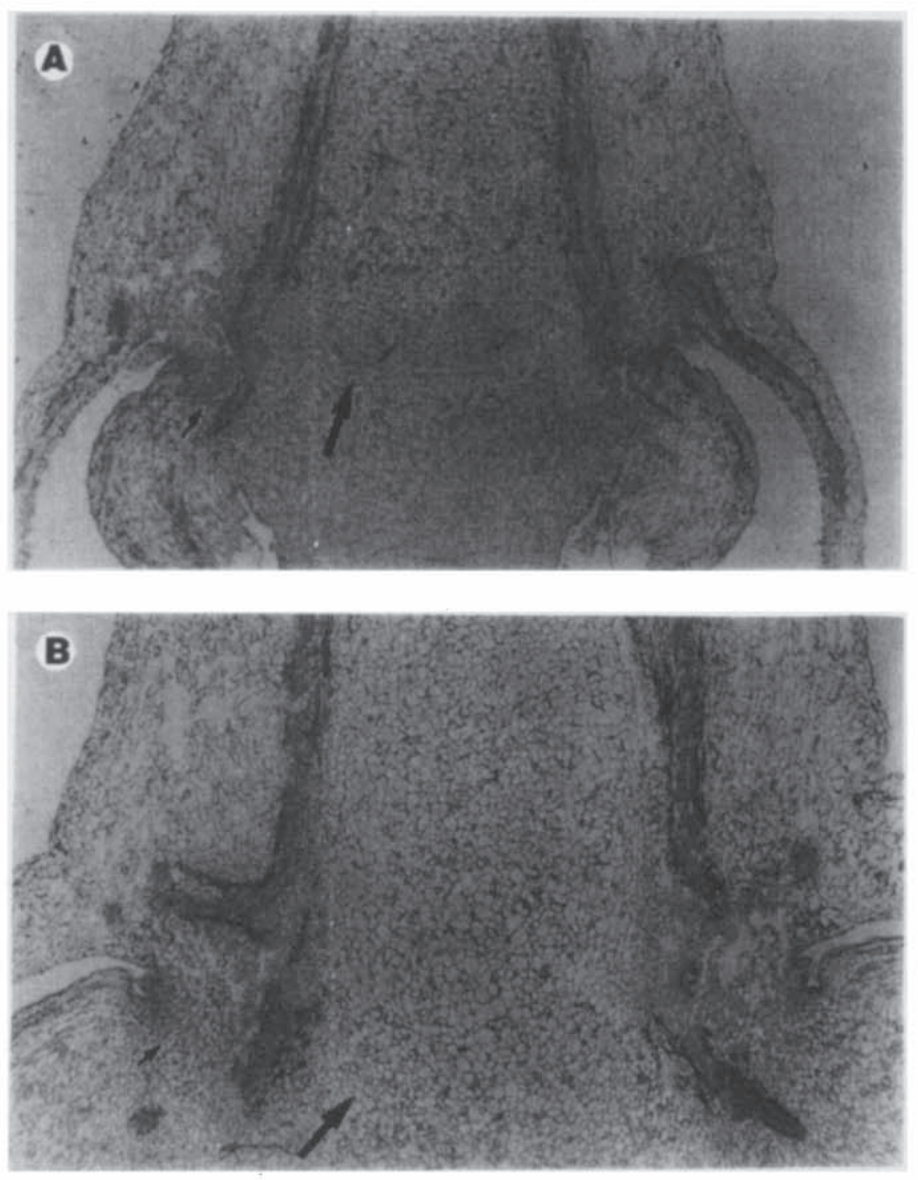

Fig. 5. Photomicrographs of longitudinal sections of cayenne pepper stained with $1.0 \%$ safranin counterstained with $1.0 \%$ alcian blue. (A) Cajun 1-9027, (B) Cap9004. Large arrows indicate sclereids in pith. Small arrows indicate sclereids in cortex. Magnification 15x. 

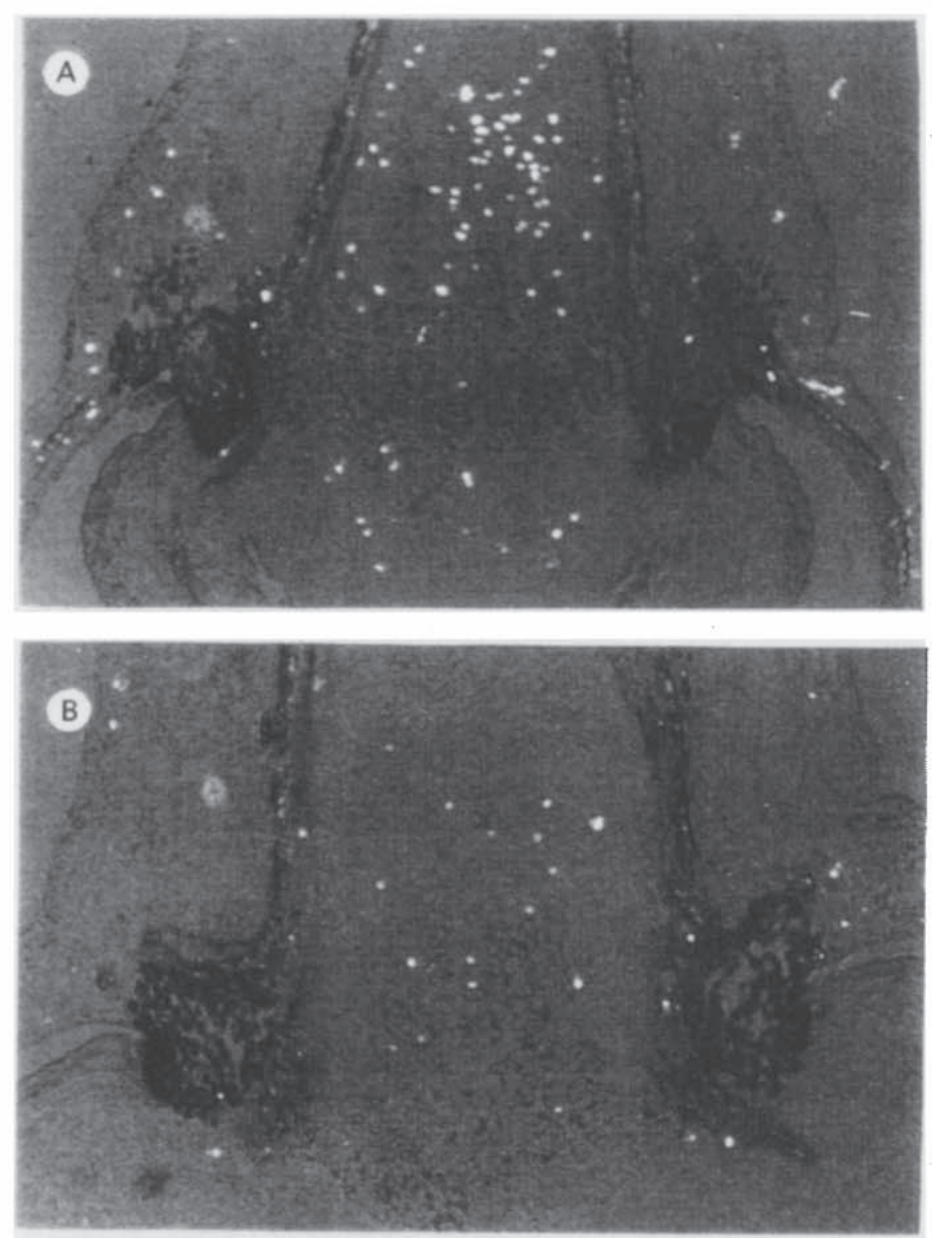

Fig. 6. Photomicrographs of longitudinal sections of cayenne pepper with polarized light (illustration of lignification). (A) Cajun 1-9027, (B) Cap-9004. Magnification $15 \mathrm{x}$.

indicating genetic control (Setiamihardja and Knavel, 1990; Smith, 1951; Spasojevec and Webb, 1971; Werner and Honma, 1980). Seasonal influence on FDF for some genotypes may indicate increased physiological or developmental sensitivity to environmental factors. Wien et al. (1989) reported that the susceptibility of stress-induced abscission decreased with the age of the tissue and indicated that mature fruit were most resistant. Screening methods have been developed to identify genotypes resistant to stress-induced abscission.

In the genotypes examined, correlations between FDF and phenotypic characters of fruit length and diameter, pedicel length, calyx diameter, length, or scar were not consistent. This inconsistency suggests that using fruit characteristics would not be useful for breeding low-FDF genotypes.

Table 2. Volume density $\left(\mathrm{V}_{\mathrm{v}}\right)$ of cell structures in the fruit-receptacle detachment area of Cajun 1-9027 and Cap-9004 cayenne pepper (mean $\pm \mathrm{SE})$

\begin{tabular}{lcc}
\hline \hline & \multicolumn{2}{c}{ Genotype } \\
\cline { 2 - 3 } Structure & Cap-9004 & Cajun 1-9027 \\
\hline Parenchyma & $0.581 \pm 0.008^{* * * *}$ & $0.484 \pm 0.008$ \\
Sclerenchyma & $0.294 \pm 0.007^{* * *}$ & $0.409 \pm 0.008$ \\
Vascular tissue & $0.093 \pm 0.004^{\text {Ns }}$ & $0.099 \pm 0.005$ \\
Intercellular spaces & $0.032 \pm 0.003^{* * *}$ & $0.008 \pm 0.001$ \\
\hline
\end{tabular}

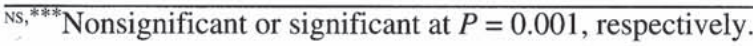

The location of clean detachment in Cap-9004 was at the fruitreceptacle junction. Although only $25 \%$ of the fruit separated in this manner, it was the only consistent break. The detachment area was not composed of a distinct layer of cells, but was delineated by the junction of the fruit and receptacle tissue just distal to the fruitreceptacle indentation. Both genotypes had this indentation, which served as a useful marker. Cells in the cortex were progressively smaller from the receptacle and fruit toward the fruit-receptacle junction, similar to the lower abscission zone in sweet cherry (Wittenbach and Bukovac, 1972). Another similarity of cayenne pepper genotypes to sweet cherry was the branching of the vascular cylinder in the detachment area. Although Wittenbach and Bukovac (1972) found no lignification of cells on either side of the abscission layer, both cayenne pepper genotypes had sclereids in the fruit-receptacle junction region. However, quantitative examination of the detachment area suggests possible genotypic differences. The volume of sclereids in Cap-9004 was less than that in Cajun 1-9027. According to Wittenbach and Bukovac (1972), a lower sclereid volume would probably weaken the detachment area and increase ease of detachment. Characteristically, lignin is absent or present in only very limited amounts in abscission zone cells, and it is unlikely that the cells of the cortex of the abscission zone would undergo lignification (Baird and Webster, 1979). More lignification throughout the detachment area in Cajun 19027 than Cap-9004 could contribute to the increased detachment force needed for fruit removal.

Wittenbach and Bukovac (1972) suggested that the most significant component of fruit abscission may be fruit ripening. In our study, fruit maturity was sequenced and collections were make at the same stage of ripeness to minimize this as a factor in differences between the two genotypes. Although firmness was not tested in our study, there was no evidence of soft flesh (Smith, 1951) in either genotype at the time of sampling. Fruit from both genotypes were firm when red. Baird and Webster (1979) suggested that mechanical resistances influence the ultimate degree of separation in many fruit. This could explain the difference in fruit detachment in the two genotypes studied. The increased volume of sclereids and decreased volume of intercellular space in Cajun 1-9027, as well as the arrangement and size of the cells, may be responsible for the increased force required to detach the fruit compared with Cap-9004. Cajun 1-9027 may have been structurally stronger with a continuous disk of small thick-walled cells through the fruitreceptacle junction region. Cap-9004 had small thick-walled cells mainly in the cortex with larger thin-walled cells in the pith and greater intercellular space than Cajun 1-9027, possibly resulting in a structurally weaker detachment area in this genotype. Future research investigating other genotypes differing in FDF for differences in cellular structure and organization will help determine the significance of these findings to cayenne pepper in general.

\section{Literature Cited}

Baird, L.A.M. and B.D. Webster. 1979. The anatomy and histochemistry of fruit abscission, p. 172-203. In: J. Janick (ed.). Horticultural reviews. vol 1. AVI, Westport, Conn.

Batal, K.M. and D.M. Granberry. 1982. Effects of growth regulators on ripening and abscission of pimento and paprika peppers. HortScience 17:944-946.

Beaudry, R.M. and S.J. Kays. 1988. Effect of ethylene source on abscission of pepper plant organs. HortScience 23:742-744.

Berlyn, G.P. and J.P. Miksche. 1976. Botanical microtechnique and cytochemistry. Iowa State Univ. Press, Ames.

Boudreaux, J.E., H.K. Whitam, and D.K. Pollet. 1992. Bell pepper production. La. Coop. Ext. Serv. La. State Univ. Agr. Ctr. Publ. 2471 
Jensen, W.A. 1962. Botanical histochemistry. W.H. Freeman and Co., San Francisco.

Motsenbocker, C.E. 1996. Detachment force and fruit characteristics of tabasco pepper at different stages of development. HortScience 31:12311233.

Petoseed. 1993. Specialty pepper market. Petoseed Co. Inc. Bul.

Setiamihardja, R. and D.E. Knavel. 1990. Association of pedicel length and diameter with fruit length and diameter and ease of fruit detachment in pepper. J. Amer. Soc. Hort. Sci. 115:677-681.

Smith, P.G. 1951. Deciduous ripe fruit character in peppers. Proc. Amer. Soc. Hort. Sci. 57:343-344.

Smith, P.G., B. Villalon, and P.L. Villa. 1987. Horticultural classification of peppers grown in the United States. HortScience 22:11-13.
Spasojevic V. and R.E. Webb. 1971. Inheritance of the abscission of ripe pepper from its calyx. Arhiv. Bioloskih. Nauka. 23:115-119.

Toth, R. 1982. An introduction to morphometric cytology and its application to botanical research. Amer. J. Bot. 69:1694-1706.

Werner, D.J. and S. Honma. 1980. Inheritance of fruit detachment force in pepper. J. Amer. Soc. Hort. Sci. 105:805-807.

Wien, H.C., K.E. Tripp, R. Hernandez-Armenta, and A.D. Turner. 1989. Abscission of reproductive structures in pepper: Causes, mechanisms, and control, p. 150-165. In: S. K. Green (ed.). Tomato and pepper production in the tropics. Tainan, Taiwan.

Wittenbach, V.A. and M.J. Bukovac. 1972. An anatomical and histochemical study of abscission in maturing sweet cherry fruit. J. Amer. Soc. Hort. Sci. 97:214-219. 